NASA/TM-2002-210723

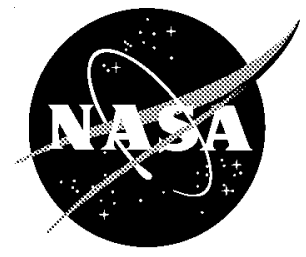

\title{
Wing Torsional Stiffness Tests of the Active Aeroelastic Wing F/A-18 Airplane
}

William A. Lokos, Candida D. Olney, Natalie D. Crawford, Rick Stauf, and Eric Y. Reichenbach NASA Dryden Flight Research Center

Edwards, California

May 2002 


\section{The NASA STI Program Office...in Profile}

Since its founding, NASA has been dedicated to the advancement of aeronautics and space science. The NASA Scientific and Technical Information (STI) Program Office plays a key part in helping NASA maintain this important role.

The NASA STI Program Office is operated by Langley Research Center, the lead center for NASA's scientific and technical information. The NASA STI Program Office provides access to the NASA STI Database, the largest collection of aeronautical and space science STI in the world. The Program Office is also NASA's institutional mechanism for disseminating the results of its research and development activities. These results are published by NASA in the NASA STI Report Series, which includes the following report types:

- TECHNICAL PUBLICATION. Reports of completed research or a major significant phase of research that present the results of NASA programs and include extensive data or theoretical analysis. Includes compilations of significant scientific and technical data and information deemed to be of continuing reference value. NASA's counterpart of peer-reviewed formal professional papers but has less stringent limitations on manuscript length and extent of graphic presentations.

- TECHNICAL MEMORANDUM. Scientific and technical findings that are preliminary or of specialized interest, e.g., quick release reports, working papers, and bibliographies that contain minimal annotation. Does not contain extensive analysis.

- CONTRACTOR REPORT. Scientific and technical findings by NASA-sponsored contractors and grantees.
- CONFERENCE PUBLICATION. Collected papers from scientific and technical conferences, symposia, seminars, or other meetings sponsored or cosponsored by NASA.

- SPECIAL PUBLICATION. Scientific, technical, or historical information from NASA programs, projects, and mission, often concerned with subjects having substantial public interest.

- TECHNICAL TRANSLATION. Englishlanguage translations of foreign scientific and technical material pertinent to NASA's mission.

Specialized services that complement the STI Program Office's diverse offerings include creating custom thesauri, building customized databases, organizing and publishing research results...even providing videos.

For more information about the NASA STI Program Office, see the following:

- Access the NASA STI Program Home Page at http://www.sti.nasa.gov

- E-mail your question via the Internet to help@sti.nasa.gov

- Fax your question to the NASA Access Help Desk at (301) 621-0134

- Telephone the NASA Access Help Desk at (301) 621-0390

- Write to:

NASA Access Help Desk

NASA Center for AeroSpace Information 7121 Standard Drive Hanover, MD 21076-1320 
NASA/TM-2002-210723

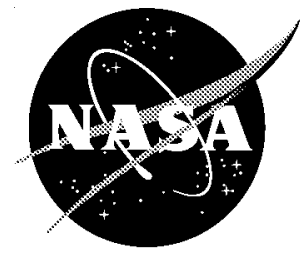

\section{Wing Torsional Stiffness Tests of the Active Aeroelastic Wing F/A-18 Airplane}

William A. Lokos, Candida D. Olney, Natalie D. Crawford, Rick Stauf, and Eric Y. Reichenbach NASA Dryden Flight Research Center

Edwards, California

National Aeronautics and

Space Administration

Dryden Flight Research Center

Edwards, California 93523-0273

May 2002 


\section{NOTICE}

Use of trade names or names of manufacturers in this document does not constitute an official endorsement of such products or manufacturers, either expressed or implied, by the National Aeronautics and Space Administration.

Available from the following:

NASA Center for AeroSpace Information (CASI)

7121 Standard Drive

Hanover, MD 21076-1320

(301) 621-0390
National Technical Information Service (NTIS) 5285 Port Royal Road Springfield, VA 22161-2171

(703) $487-4650$ 


\title{
WING TORSIONAL STIFFNESS TESTS OF THE ACTIVE AEROELASTIC WING F/A-18 AIRPLANE
}

\author{
William A. Lokos ${ }^{*}$, Candida D. Olney ${ }^{\dagger}$, and Natalie D. Crawford ${ }^{\ddagger}$ \\ NASA Dryden Flight Research Center \\ Edwards, California \\ Rick Stauf ${ }^{\S}$ \\ Spiral Technology Inc. \\ Lancaster, California \\ Eric Y. Reichenbach \\ The Boeing Company \\ St. Louis, Missouri
}

\begin{abstract}
$\underline{\text { Abstract }}$
The left wing of the Active Aeroelastic Wing (AAW) F/A-18 airplane has been ground-load-tested to quantify its torsional stiffness. The test has been performed at the NASA Dryden Flight Research Center in November 1996, and again in April 2001 after a wing skin modification was performed. The primary objectives of these tests were to characterize the wing behavior before the first flight, and provide a before-and-after measurement of the torsional stiffness. Two streamwise load couples have been applied. The wing skin modification is shown to have more torsional flexibility than the original configuration has. Additionally, structural hysteresis is shown to be reduced by the skin modification. Data comparisons show good repeatability between the tests.
\end{abstract}

\section{$\underline{\text { Nomenclature }}$}

$\begin{array}{ll}\text { AAW } & \text { Active Aeroelastic Wing } \\ \text { FEM } & \text { finite-element model } \\ x, y, z & \text { Cartesian coordinates }\end{array}$

\footnotetext{
* Aerospace Engineer

${ }^{\dagger}$ Aerospace Engineer

*Aerospace Engineer, Member

$\S_{\text {Structural Flight Test Engineer }}$

Aerospace Engineer, Member
}

Copyright (C) 2002 by the American Institute of Aeronautics and Astronautics, Inc. No copyright is asserted in the United States under Title 17, U.S. Code. The U.S. Government has a royalty-free license to exercise all rights under the copyright claimed herein for Governmental purposes. All other rights are reserved by the copyright owner. $\underline{\text { Introduction }}$

For more than a decade, wing torsional flexibility has been proposed to aeroelastically enhance the roll maneuverability of high-performance aircraft. ${ }^{1}$ Although aileron reversal-related aeroelastic control behavior has always been avoided, even if it meant additional structural weight; when the behavior is incorporated as a preprogrammed control mode, some significant benefits might be reaped. When the mode is designed into a new airframe, reduced weight, increased maneuverability, and other advantages can be exploited. ${ }^{2}$

A NASA F/A-18 airplane (fig. 1) has been structurally modified to support this type of research. ${ }^{3}$ The cover panels on the aft wing box were replaced with more flexible panels to replicate the stiffness of the original preproduction F/A-18 aircraft. Figure 2 shows configurations for the aft wing box cover panels before and after the Active Aeroelastic Wing (AAW) modification. The first preproduction version of the F/A18 aircraft was found to have the potential for aileron reversal within its performance envelope, which makes the configuration ideal for demonstrating AAW technology. Production F/A-18 aircraft were built with stiffer wings to preclude this tendency and increase roll performance through the use of conventional wing control surfaces and asymmetric stabilator.

Early in the AAW project, structural testing was anticipated to have an important role in accomplishing project objectives. ${ }^{4}$ In November 1996, prior to the AAW modification, the wing was tested to quantify its baseline torsional stiffness. These tests were used to modify the baseline F/A-18 finite-element model (FEM) 


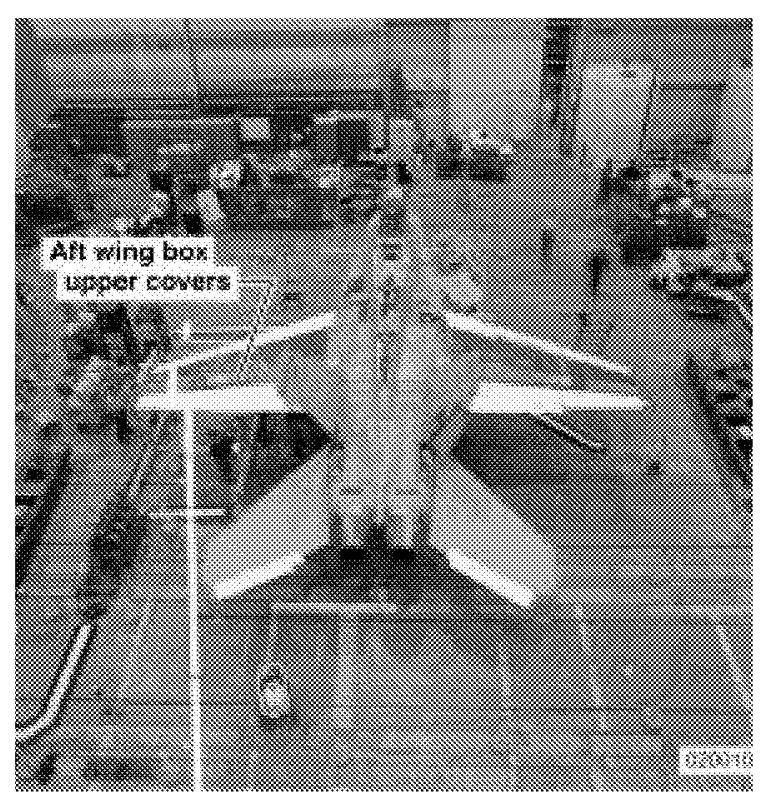

Figure 1. The AAW F/A-18 airplane.

to create the AAW model, which is used for aeroelasticity predictions and control law development. The data from the 1996 tests were intended to provide upper and lower bounds for the results that would be obtained from the AAW configuration.

In April 2001, after the AAW modification work was performed, a repeat series of stiffness tests was conducted. Deflections from these tests were compared in real time and after the test to the AAW analytical model predictions to evaluate the accuracy of the model stiffness and to determine whether modifications to the model were necessary.

The objectives of the wing torsional stiffness tests were to:

- establish a baseline torsional stiffness signature for the wing before AAW modification.

- establish the maximum possible torsional flexibility increment that theoretically could be produced by modifying the aft wing box cover panels.

- characterize the torsional stiffness of the modified wing.

- make a direct comparison of the wing stiffness before and after structural modification and provide an assessment of the modification effectiveness.

- validate the repeatability of the testing method.

- make comparisons with FEM predictions.

\section{Baseline configuration}

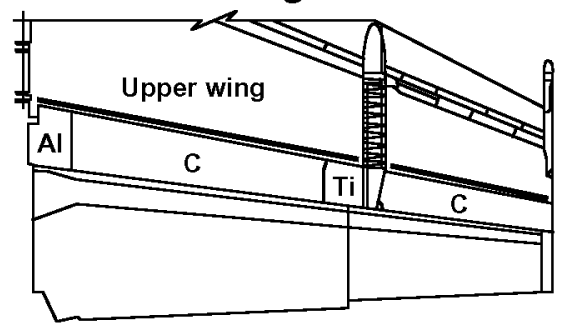

Inboard wing: 3 panels

Outboard wing: 1 panel

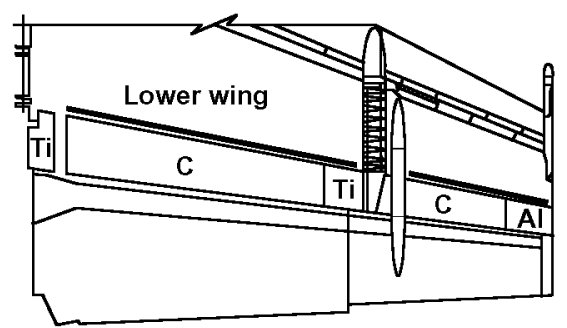

Inboard wing: 3 panels

Outboard wing: 2 panels

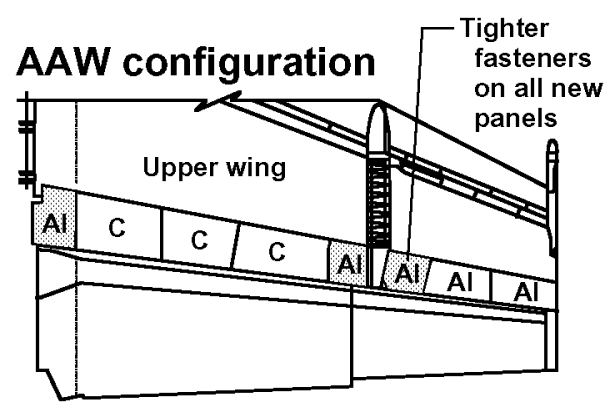

Inboard wing: 5 panels

Outboard wing: 3 panels

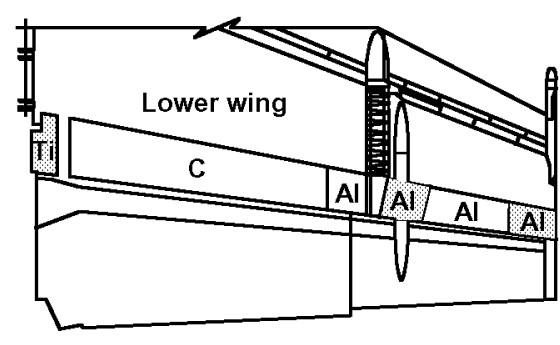

Inboard wing: 3 panels

Outboard wing: 3 panels

020001

Figure 2. Aft wing box cover panel modifications. 


\section{$\underline{\text { Test Setup }}$}

All testing was performed at the NASA Dryden Flight Research Center (Edwards, California) Flight Loads Laboratory, ${ }^{5}$ and data were acquired and displayed by the laboratory data acquisition and control system. The tasks for test setup included the installation of aircraft constraints, instrumentation, and loading hardware.

The airplane was restrained at the main landing gear, the arresting hook, and the nose gear. In the 1996 test, the main gear was depressurized, supported with short jacks, and chained to the floor. In the 2001 test, the main gear was entirely removed and replaced with a restraint fixture (fig. 3). This change was not because of any inadequacy of the original support, but was to provide for a strain gage loads calibration test that was performed immediately after the 2001 stiffness test. That subsequent testing is what necessitated including the provision for locking the wing control surfaces. In both the 1996 and 2001 tests, the arresting hook was replaced with a support fixture (fig. 4) that prevented pitching. The nose gear was held down with loose chains for additional safety. The forward fuselage was allowed to "float" on the pressurized nose gear. Test hardware was designed for a factor of safety of 3.0 or more.

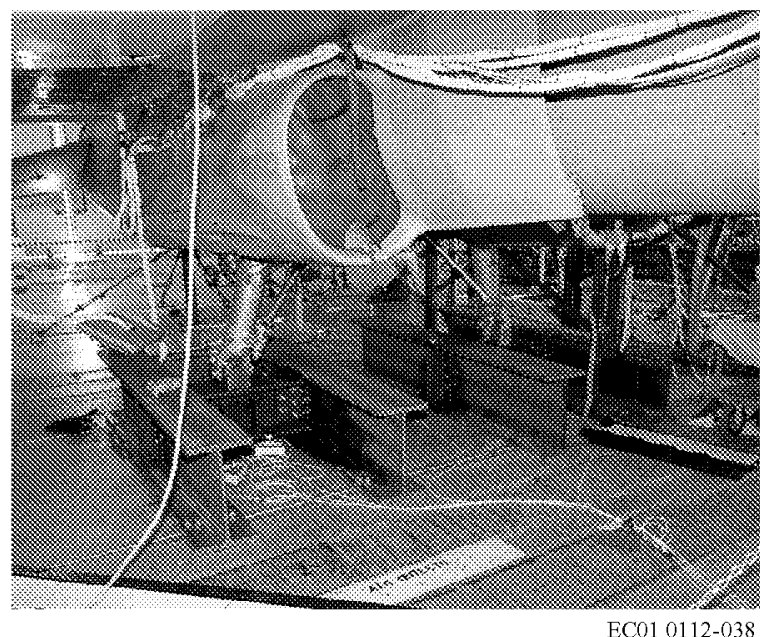

Figure 3. Main gear restraints.

Deflection potentiometers were installed to quantify elastic vertical deflections of the left wing and monitor any rigid-body motion of the overall airframe (figs. 5 and 6). A total of 48 left wing displacements was measured by a combination of digital dial gauges and

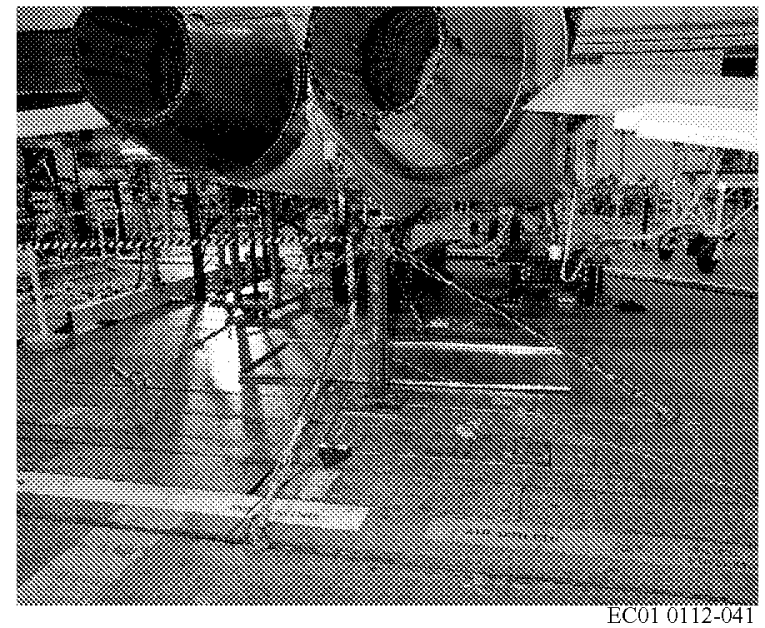

Figure 4. Tailhook restraint.

string potentiometers arrayed along the front spar, an intermediate spar, the rear spar, and the aft spar. These transducers were installed in the same locations in both the 1996 and 2001 tests.

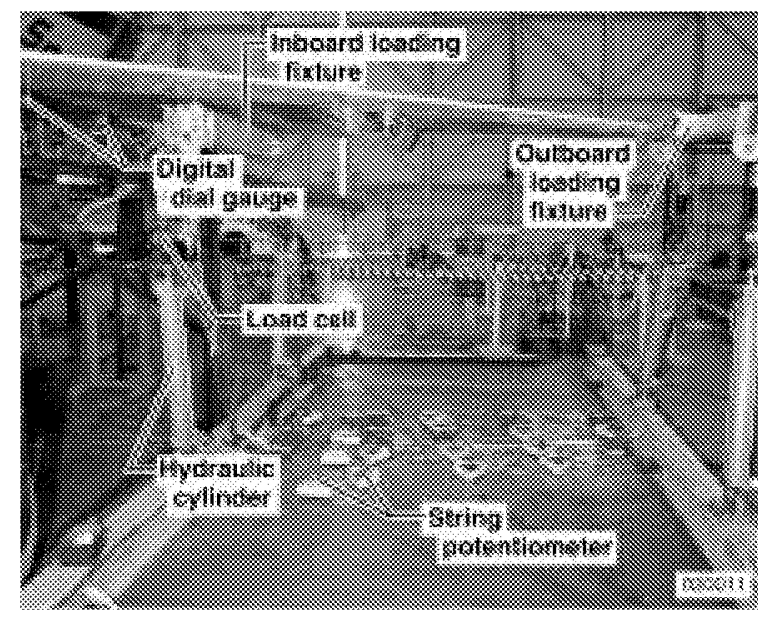

Figure 5. Load columns and instrumentation setup.

During the 2001 test, these transducer locations were more precisely determined using a theodolite spacial coordinate measurement system. String potentiometers were also installed along the fuselage centerline (four), the main gear restraint fixture (two), the horizontal tail tips (two), and the right wing (four) to monitor any rigid-body motion. Any indication of rigid-body motion during loading would have revealed a problem with 


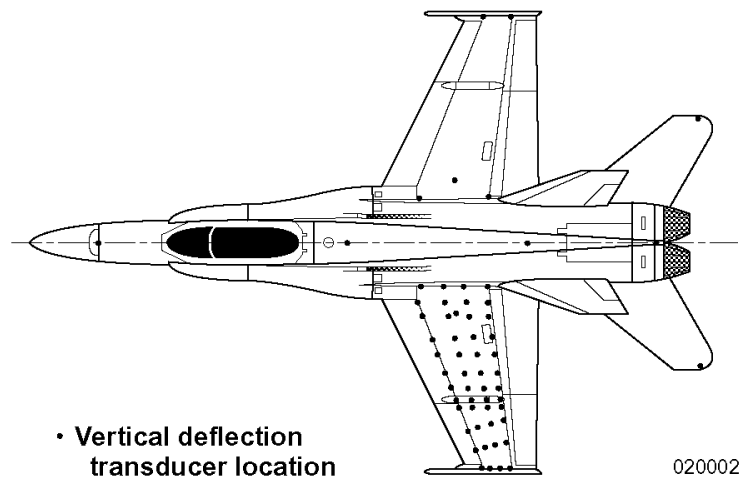

Figure 6. Vertical deflection instrumentation.

aircraft constraints. Aside from enhancing safety, ensuring that no rigid-body motion occurred also helped guarantee data quality, because any airframe shifting would corrupt the measurement of elastic wing displacements.

Loading fixtures were attached to the left wing at two span stations (fig. 5). Four hydraulic cylinders coupled to load cells that have a 5000-lb operating range were vertically aligned with the loading fixtures. During testing, the streamwise load column pairs were actuated to equal magnitudes in opposite directions. Inboard and outboard torque moments were always applied in phase. Complete load cycles included full positive and negative torque moment sweeps. Each test began with a stepped run for preconditioning, then a smooth sweep was performed for data. Figure 7 shows a typical data run load time history. The loading rate was 30 percent of the test limit load each minute.

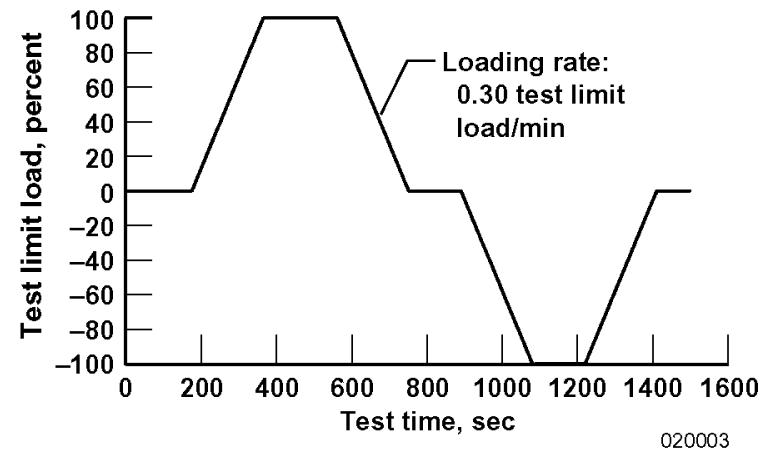

Figure 7. Typical load profile.

Table 1 shows the five F/A-18 configurations tested. The 1996 testing of the wings before AAW modification involved two configurations: with all the cover panels installed, and with the upper aft box cover panels off. In both of these conditions, the wing control surfaces were not locked but were held in their neutral positions only by drive system friction. The 2001 testing of the AAW-modified wings involved three configurations: with new upper and lower aft box cover panels installed and wing control surfaces locked in position; with new aft box cover panels installed and wing control surfaces not locked in position; and with upper aft box cover panels off, new lower aft box cover panels on, and wing control surfaces not locked in position.

Data were simultaneously displayed in multiple locations for safety-of-test and real-time data quality verification. Data were recorded at two samples/sec. Measured wing deflections were compared in real time with FEM-predicted deflections for added safety. The data system was calibrated and zeroed each day. Figure 8 shows a composite photograph of the left wingtip under the maximum up, neutral, and maximum down loading conditions.

Table 1. Ground test configurations.

\begin{tabular}{ccl}
\hline \hline $\begin{array}{c}\text { Configuration } \\
\text { number }\end{array}$ & Test year & \multicolumn{1}{c}{ Configuration description } \\
\hline 1 & 1996 & Baseline with all panels on, no control surfaces locked \\
2 & 1996 & Baseline with upper aft box cover panels off, no control surfaces locked \\
3 & 2001 & Modified wings with all panels on, wing control surfaces locked \\
4 & 2001 & Modified wings with all panels on, wing control surfaces not locked \\
5 & 2001 & Modified wings with upper aft box panels off, wing control surfaces not locked \\
\hline \hline
\end{tabular}




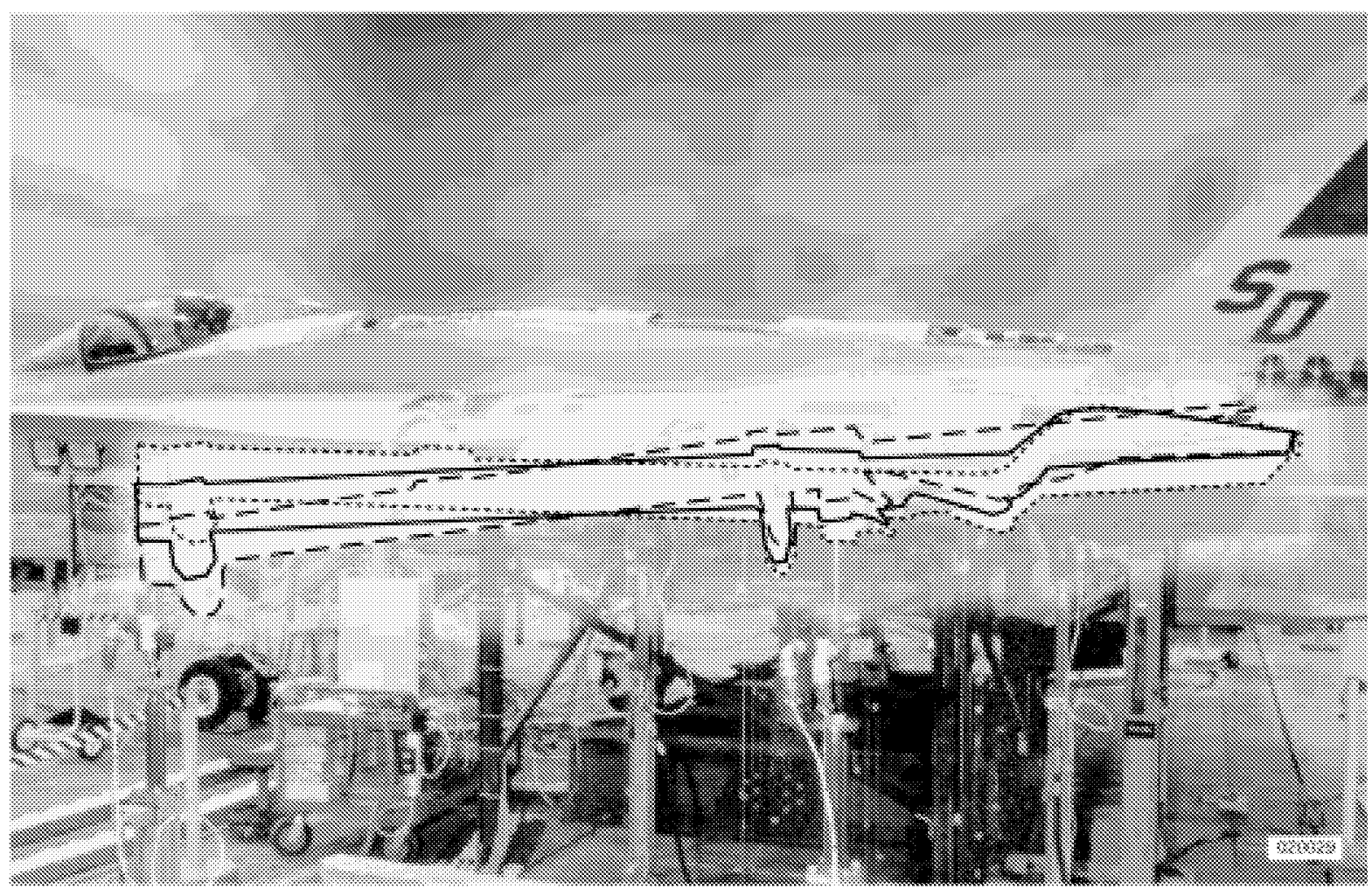

Figure 8. Composite photograph of wing deformed at maximum up, neutral, and maximum down torque.

\section{Analytical Model}

The AAW FEM (fig. 9) used in this study is a contractor-built stiffness model designed to approximate the expected deflections under load for the modified wing. This linear model represents the left side of the F/A-18 airplane, including the fuselage, wing, and empennage. The AAW FEM consists of 854 nodes, 2418 elements, and 191 rigid elements. The 2418 elements include point, quadrilateral, and bar elements. The point elements are used to apply concentrated masses to the vehicle. The quadrilateral elements are used to represent both the wing skin and the shear webs for the ribs and the spars. The bar elements are used as spar and rib caps and to approximate spanwise stiffness of the control surfaces. The rigid elements are used to connect the nodes of the control surfaces in the chordwise direction, to connect the control surfaces to the aircraft wing, and to represent the wing fold.

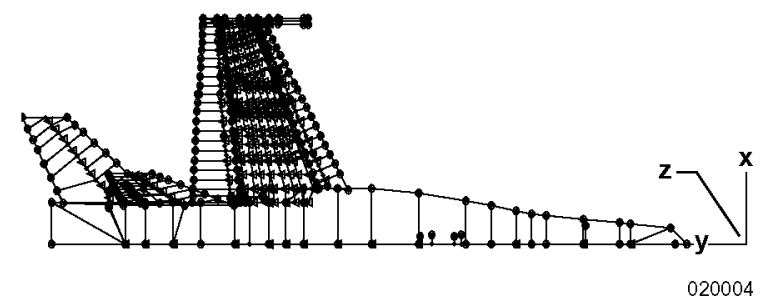

Figure 9. Finite-element model.

To represent the ground test as accurately as possible, both the aircraft restraints and the wing loads were evaluated before including their equivalent constraints and loads. Constraints were placed on the corresponding model nodes. For the main landing gear node, only the pitch degree of freedom was left unconstrained. At the tailhook attachment point, the node was constrained in all degrees of freedom except for the pitch and lateral-displacement degrees of freedom. 
The load couples, which were applied to the model, also had to be functionally equivalent to those placed on the vehicle. Because the nodes used in the loads model were not exactly in the same place as the fixture attachment points on the vehicle, the load values used in the model had to be modified so that the resulting root bending and torque were the same as those applied to the vehicle during the ground test. The AAW FEM-predicted deflections then were compared to those deflections obtained during the ground test.

\section{Data Analysis Method}

To calculate the elastic twist increment (as measured at the wingtip) for each applied torque moment, the following steps were performed for each test configuration:

1. Data were processed to produce deflection curves along the front spar, an intermediate spar, the rear spar, and the aft spar (fig. 10).

2. A sixth-order polynomial curve fit was selected to produce representative line equations for each of these spars. Curve fitting was used to accommodate displacement measurements taken in nonstreamwise locations.

3. From these equations, deflections were calculated at 12 span stations for each of the 4 spar lines producing plots such as those shown in figure 11 . Chordwise bending is apparent in these curves. For example, during trailing-edge-down torque, the tip shows chordwise bending that is concave inboard transitions to convex towards the tip.

4. Linear least-squares curve fits were done for each of these chordlines.

5. The arcsine of the slope of each of these lines then was plotted, yielding spanwise twist distributions (fig. 12).

6 . This process then was repeated at every point throughout the load range using automated routines to produce wingtip twist as a function of load (fig. 13).

7. Wing torsional stiffness values for each wing configuration were calculated using the least squares method.

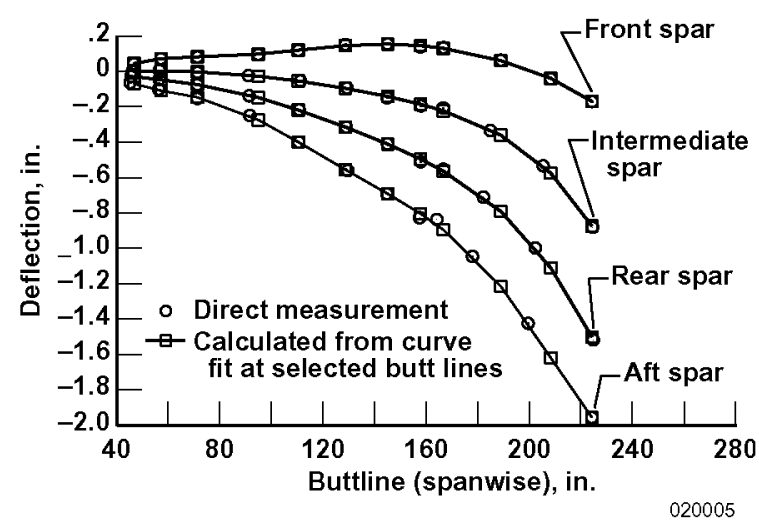

Figure 10. Measured deflections along constant percent chord lines for 1996 baseline (Configuration 1) at maximum applied load.

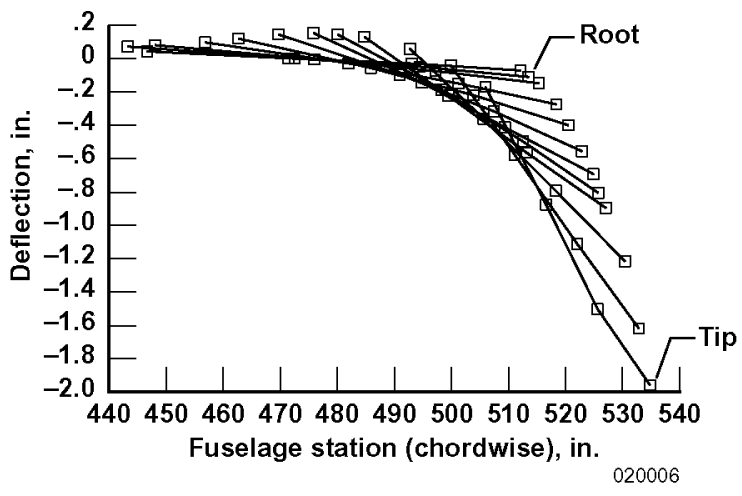

Figure 11. Calculated deflections along selected buttlines for 1996 baseline (Configuration 1) at maximum applied load.

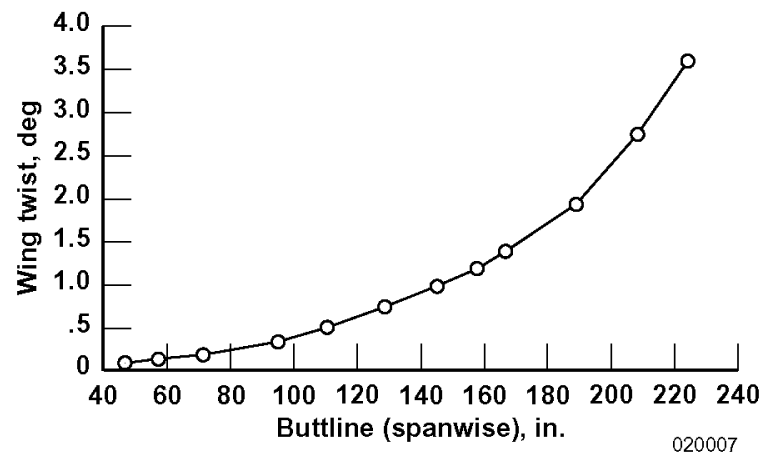

Figure 12. Calculated wing twist as a function of buttline for 1996 baseline (Configuration 1) at maximum applied load. 


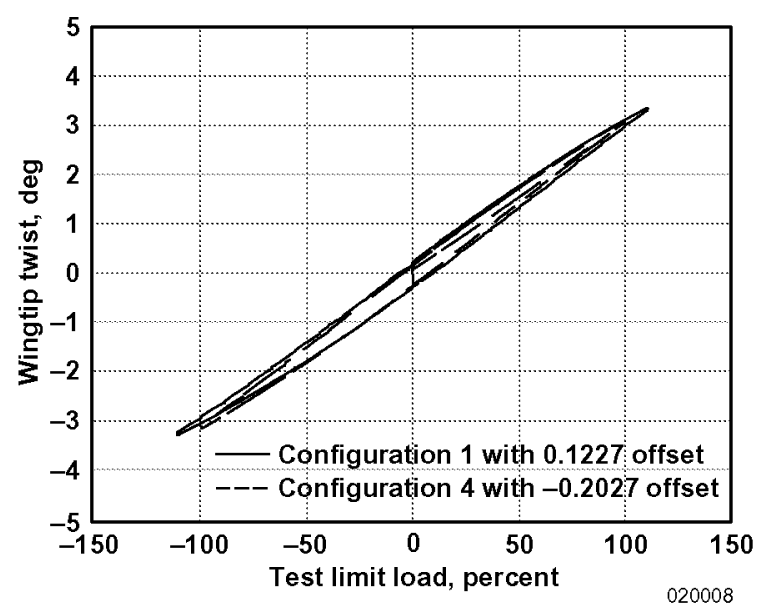

Figure 13. Comparison of pre- and post-AAW mod twist response.

\section{Error Analysis}

An important consideration with test data analysis is evaluating the uncertainty associated with the measurement error. The overall twist angle error is addressed here using test configuration 4 (table 1) as a representative case. This absolute wing twist error increases when assessing the two load cases with the aft wing box cover panels removed, because the wing flexibility is greater with the panels removed.

The measurement error comes from two main sources. The dominant factor comes from a 0.25 -in. radial error when quantifying locations of the digital dial gauges and deflection potentiometers on the lower surface of the left wing. This radial error includes consideration of uncertainty in placement repeatability from the 1996 tests to the 2001 tests. The locations for dial gauges and deflection potentiometers were placed on the airplane to replicate the locations used in the test performed in 1996. The locations were placed by hand using the same fastener pattern drawings of the left wing from 1996. Figure 6 shows these locations.

As previously mentioned, a theodolite measuring system was used to determine the coordinates of the instrumentation in the aircraft coordinate system. These coordinates then were used in the data analysis. The associated measurement error in the fuselage direction produces an overall twist angle error of $\pm 0.05^{\circ}$ from the leading to trailing edge at the wingtip. This twist angle error associated with location uncertainty in the spanwise direction is negligible.

The second source of the measurement error is caused by the mechanical nature of the digital dial gauges and deflection potentiometers. One type of digital dial gauge and three different sizes of deflection potentiometers were used. Table 2 shows the manufacturer's error specifications.

These transducer errors produce a wing twist angle error of $\pm 0.02^{\circ}$. Errors caused by data acquisition, measurement system calibration, applied loads, and nonlinear curve fitting are negligible. Therefore, the overall estimated error in the total wing twist calculation for the $2001 \mathrm{AAW}$ wing torsional stiffness test (with the aft wing box cover panels on and the control surfaces unlocked) data in this report is $\pm 0.07^{\circ}$.

\section{$\underline{\text { Results }}$}

Figure 13 shows wingtip twist data from the 1996 and 2001 tests plotted as a function of percent load. Structural hysteresis is noted in the height of the data loop at zero load. Comparison of the heights of the hysteresis loops in these two plots indicates a reduction of structural hysteresis in the modified wing compared

Table 2. Instrumentation accuracy for the twist test.

\begin{tabular}{lccc}
\hline \hline \multicolumn{1}{c}{ Instrumentation } & $\begin{array}{c}\text { Range, } \\
\text { in. }\end{array}$ & Accuracy & $\begin{array}{c}\text { Number used } \\
\text { on left wing }\end{array}$ \\
\hline Digital dial gauges & 1 & 0.00012 in. $^{\#}$ & 19 \\
Deflection potentiometers & 1 & 1.0 percent $^{* *}$ & 11 \\
& 3 & 1.0 percent $^{* *}$ & 15 \\
& 6 & 0.5 percent $^{* *}$ & 3 \\
\hline \hline
\end{tabular}

\footnotetext{
${ }^{\#}$ Consistent error

${ }^{* *}$ Independent linearity error
} 
to the wing before AAW modification. This reduction is attributed to the significant effort invested in improving the fastener fit for the upper and lower aft wing box cover panels and some main wing box fasteners as well. Anecdotal data indicate that before the AAW modifications, these wings had loose fastener fit (many were worn beyond production tolerance); but the reworked wings have very tight fasteners. The AAW fastener rework should improve the quality of all flight data that are subject to wing hysteresis.

This structural hysteresis must be considered when making comparisons between load cases with dissimilar load profiles. The residual "set" of the wing after a positive applied torque biases response to subsequent load in the opposite manner of that produced by a negative applied torque. In this case, hysteresis offsets were manually eliminated by shifting each data set so that the initial twist at zero load is zero, allowing a direct comparison to be made. Comparison of the 1996 data for the configurations with aft wing box cover panels on and off indicates a flexibility increase of 24.23 percent (table 3), which is considered the maximum flexibility increment possible through modification to the panels. The slight " $S$ " shape seen in these twist curves is attributed to "load stiffening," which occurs when more of the local structure begins to share load as fastener tolerances are overcome.

Table 3. Torsional stiffness comparison.

\begin{tabular}{ccc}
\hline \hline $\begin{array}{c}\text { Test } \\
\text { configuration }\end{array}$ & $\begin{array}{c}\text { Wingtip } \\
\text { flexibility, } \\
\text { deg/in-klbf }\end{array}$ & $\begin{array}{c}\text { Flexibility } \\
\text { increase, } \\
\text { percent }\end{array}$ \\
\hline 1 & 0.007525 & \\
2 & 0.009348 & 24.23 \\
3 & 0.007768 & 3.22 \\
4 & 0.007772 & 3.28 \\
5 & 0.009194 & 22.17 \\
AAW & & 46.62 \\
FEM & 0.011033 & \\
\hline \hline
\end{tabular}

Comparison of the 1996 and 2001 tests for the configurations with the panels on shows a flexibility increment of 3.28 percent. Comparison of the 1996 and the 2001 tests for the configurations with the panels off (fig. 14) shows approximately 2-percent difference, which validates the comparability of the testing methodologies employed. Table 3 shows a summary of these observations. The wing torsional flexibility values shown were calculated from the slope of the least squares fit of wingtip twist versus total applied wing root torque. Comparison of the results from the 2001 test conditions of panels on and control surfaces locked (configuration 3) and panels on and control surfaces unlocked (configuration 4) reveals that no effect on wing torsional stiffness existed because of this change in control surface rigging. No significant rigid-body deflections were observed in any of the 1996 or 2001 tests, indicating good performance of the restraint fixtures.

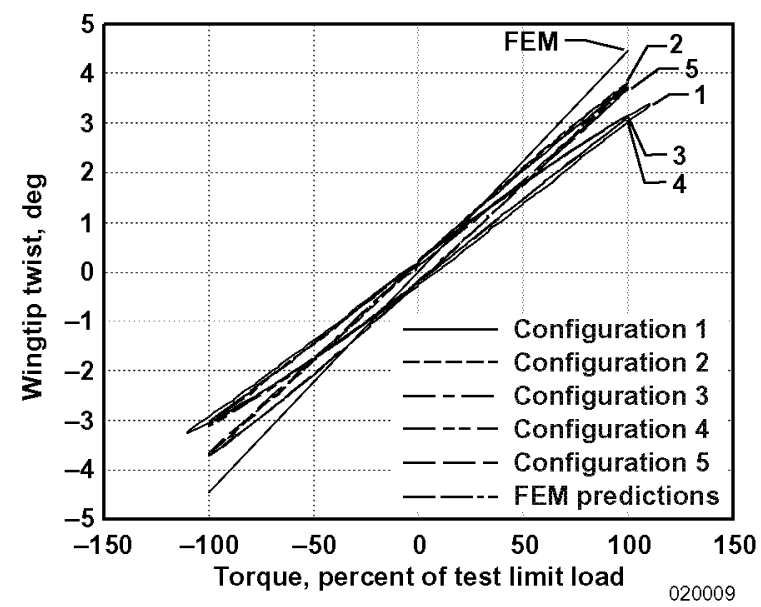

Figure 14. Summary of wing tip twist as a function of the percent test limit load.

An in-house analysis was performed in which the deflections from the finite-element analysis (previously described) were compared with the results from the ground tests. The maximum wingtip twist from the analytical model was $\pm 4.47^{\circ}$ (fig. 14), which resulted in a wingtip flexibility increase of 47 percent over the 1996 wing twist test. The original intention was to modify the AAW stiffness FEM using the results from the 1996 tests with panels on (configuration 1) and panels off (configuration 2) to bracket the expected flexibility of the $A \mathrm{AW}$ configuration. These results indicate that the stiffness of the AAW FEM was excessively reduced during model tuning, resulting in the AAW analytical model overpredicting the flexibility of the AAW wing by 42 percent. The FEM has been corrected using the latest test results and now should prove useful for aeroelastic predictions and control law development. 


\section{$\underline{\text { Summary and Conclusions }}$}

1. The modified Active Aeroelastic Wing (AAW) is slightly more than 3 percent more flexible than the baseline F/A-18 wing. This increment in flexibility is approximately 15 percent as great as that produced by removing the upper aft wing box cover panels from the standard wing.

2. The characteristic hysteresis of the modified wing is slightly less than that of the wing before AAW rework. This reduction is attributed to the significant effort invested in improving the fastener fit and should improve the quality of all flight data that are subject to wing hysteresis. The effect of the structural hysteresis of the wing is significant, and the resultant wing "set" must be properly accounted for when making stiffness comparisons, especially when variation exists in preconditioning half cycles from one load run to the next.

3. The 1996 data recorded with upper aft wing box cover panels off (configuration 2) closely match the results of the corresponding 2001 test run with upper aft wing box cover panels off (configuration 5), thereby validating the 2001 test configuration and data analysis methods.

4. Both the baseline F/A-18 and modified wings exhibit some nonlinear response attributed to "load stiffening."

5. The 2001 data reflect no torsional stiffening effect existed because of locking the inboard and outboard leading-edge flap torque shafts or substituting rigid dummy actuators for the inboard trailing-edge flap or aileron.

6. The modified wing demonstrated more torsional stiffness than was predicted by the finite-element model. The wingtip flexibility was overpredicted by the analytical model by 42 percent. The finite-element model has been modified based on the results from the 2001 stiffness test, and the error has been eliminated. Therefore, the $\mathrm{AAW}$ finite-element model can be used for aeroelasticity predictions and control law development.

\section{$\underline{\text { References }}$}

${ }^{1}$ Miller, Gerald D., "An Active Flexible Wing MultiDisciplinary Design Optimization Method," AIAA-944412-CP, Sept. 1994, pp. 1388-1394.

${ }^{2}$ Yurkovich, Rudy, "Optimum Wing Shape for an Active Flexible Wing," AIAA-95-1220-CP, April 1995, pp. $520-530$.

${ }^{3}$ Pendleton, E., D. Bessette, P. Field, G. Miller, K. Griffin, "Active Aeroelastic Wing Flight Research Program: Technical Program and Model Analytical Development," Journal of Aircraft, vol. 37, no. 4, JulyAug. 2000, pp. 554-561.

${ }^{4}$ Pendleton, Ed, Kenneth Griffin, Michael W. Kehoe, and Boyd Perry, "A Flight Research Program for Active Aeroelastic Wing Technology," AIAA-96-1574-CP, April 1996, pp. 2263-2273.

${ }^{5}$ NASA Dryden Flight Research Center, Flight Loads Laboratory: Data Acquisition and Control System (DACS) Uniform Resource Locater http://www.dfrc.nasa.gov/organizations/FLL/index.html, Sept. 2001. 
Public reporting burden for this collection of information is estimated to average 1 hour per response, including the time for reviewing instructions, searching existing data sources, gathering and maintaining the data needed, and completing and reviewing the collection of information. Send comments regarding this burden estimate or any other aspect of this collection of information, including suggestions for reducing this burden, to Washington Headquarters Services, Directorate for Information Operations and Reports, 1215 Jefferson Davis Highway, Suite 1204 , Arlington, VA 22202-4302, and to the Office of Management and Budget, Paperwork Reduction Project (0704-0188), Washington, DC 20503.

\begin{tabular}{|l|l|l|}
\hline 1. AGENCY USE ONLY (Leave blank) & $\begin{array}{l}\text { 2. REPORT DATE } \\
\text { May } 2002\end{array}$ & $\begin{array}{l}\text { 3. REPORT TYPE AND DATES COVERED } \\
\text { Technical Memorandum }\end{array}$ \\
\hline
\end{tabular}

4. TITLE AND SUBTITLE

Wing Torsional Stiffness Tests of the Active Aeroelastic Wing F/A-18

Airplane

\section{FUNDING NUMBERS}

6. AUTHOR(S)

WU 706-35-00-E8-14-00-AAW

William A. Lokos, Candida D. Olney, Natalie D. Crawford, Rick Stauf, and Eric Y. Reichenbach

7. PERFORMING ORGANIZATION NAME(S) AND ADDRESS(ES)

REPORT NUMBER

NASA Dryden Flight Research Center

P.O. Box 273

Edwards, California 93523-0273

$\mathrm{H}-2481$

9. SPONSORING/MONITORING AGENCY NAME(S) AND ADDRESS(ES)

10. SPONSORING/MONITORING

AGENCY REPORT NUMBER

National Aeronautics and Space Administration

Washington, DC 20546-0001

NASA/TM-2002-210723

11. SUPPLEMENTARY NOTES

Presented at the 43rd AIAA/ASME/ASCE/AHS Structures, Structural Dynamics and Materials Conference,

Denver, Colorado, April 2002. AIAA-2002-1333.

12a. DISTRIBUTION/AVAILABILITY STATEMENT
Unclassified-Unlimited
Subject Category 05
This report is available at http:/www.dfrc.nasa.gov/DTRS/

13. ABSTRACT (Maximum 200 words)

The left wing of the Active Aeroelastic Wing (AAW) F/A-18 airplane has been ground-load-tested to quantify its torsional stiffness. The test has been performed at the NASA Dryden Flight Research Center in November 1996, and again in April 2001 after a wing skin modification was performed. The primary objectives of these tests were to characterize the wing behavior before the first flight, and provide a before-and-after measurement of the torsional stiffness. Two streamwise load couples have been applied. The wing skin modification is shown to have more torsional flexibility than the original configuration has. Additionally, structural hysteresis is shown to be reduced by the skin modification. Data comparisons show good repeatability between the tests.

\begin{tabular}{|c|c|c|c|}
\hline \multicolumn{3}{|l|}{ 14. SUBJECT TERMS } & $\begin{array}{l}\text { 15. NUMBER OF PAGES } \\
12\end{array}$ \\
\hline \multicolumn{3}{|c|}{$\begin{array}{l}\text { Ground load testing, Wing deflection measurement, Wing elastic twist, Wing } \\
\text { flexibility, Wing torsional stiffness }\end{array}$} & 16. PRICE CODE \\
\hline $\begin{array}{l}\text { 17. SECURITY CLASSIFICATION } \\
\text { OF REPORT } \\
\text { Unclassified }\end{array}$ & $\begin{array}{l}\text { 18. SECURITY CLASSIFICATION } \\
\text { OF THIS PAGE } \\
\text { Unclassified }\end{array}$ & $\begin{array}{l}\text { 19. SECURITY CLASSIFICATION } \\
\text { OF ABSTRACT } \\
\text { Unclassified }\end{array}$ & $\begin{array}{l}\text { 20. LIMITATION OF ABSTRACT } \\
\text { Unlimited }\end{array}$ \\
\hline NSN 7540-01-280-5500 & & & $\begin{array}{l}\text { 7dard Form } 298 \text { (Rev. 2-89) } \\
\text { ribed by ANSI Std. Z39-18 } \\
02\end{array}$ \\
\hline
\end{tabular}

